\title{
Review Article \\ Monitoring Corrosion of Steel Bars in Reinforced Concrete Structures
}

\author{
Sanjeev Kumar Verma, ${ }^{1}$ Sudhir Singh Bhadauria, ${ }^{2}$ and Saleem Akhtar ${ }^{1}$ \\ ${ }^{1}$ Civil Engineering Department, University Institute of Technology, Rajiv Gandhi Technical University, Airport Road, \\ Bhopal, Madhya Pradesh 462036, India \\ ${ }^{2}$ Shri G.S. Institute of Technology and Science, Indore, Madhya Pradesh 452003, India \\ Correspondence should be addressed to Sanjeev Kumar Verma; sanjeev.apm@gmail.com
}

Received 11 August 2013; Accepted 20 October 2013; Published 16 January 2014

Academic Editors: H. Shih, İ. B. Topçu, and H.-H. Tsang

Copyright (C) 2014 Sanjeev Kumar Verma et al. This is an open access article distributed under the Creative Commons Attribution License, which permits unrestricted use, distribution, and reproduction in any medium, provided the original work is properly cited.

Corrosion of steel bars embedded in reinforced concrete (RC) structures reduces the service life and durability of structures causing early failure of structure, which costs significantly for inspection and maintenance of deteriorating structures. Hence, monitoring of reinforcement corrosion is of significant importance for preventing premature failure of structures. This paper attempts to present the importance of monitoring reinforcement corrosion and describes the different methods for evaluating the corrosion state of RC structures, especially hal-cell potential (HCP) method. This paper also presents few techniques to protect concrete from corrosion.

\section{Introduction}

Deterioration of concrete structures due to harsh environmental conditions leads to performance degradation of $\mathrm{RC}$ structures, and premature deterioration of structures before completing expected service life is major concern for engineers and researchers. Deterioration rate of structures depends on the exposure conditions and extent of maintenance. Corrosion, a result of chemical or electrochemical actions, is the most common mechanism responsible for deterioration of RC structures which is mainly governed by chloride ingress and carbonation depth of RC structures. Usually, there are two major factors which cause corrosion of rebars in concrete structures, carbonation and ingress of chloride ions. When chloride ions penetrate in concrete more than the threshold value or when carbonation depth exceeds concrete cover, then it initiates the corrosion of RC structures. If the corrosion is initiated in concrete structures, it progresses and reduces service life of the structures and rate of corrosion affects the remaining service life of RC structures. However, these severe environments can cause corrosion of reinforcement only if required amounts of oxygen and moisture are available at the rebar level in concrete structures [1].

Corrosion of steel bars is the major cause of failure of concrete structures and about two tons of concrete is used per capita of the world population every year. Therefore, it has been realized that durable structures will reduce the cement consumption. Corrosion can severely reduce the strength and life of structures and in humid conditions pollutants from atmosphere percolate through the concrete cover and cause corrosion of steel. After the initiation of corrosion in reinforcing steel, products of corrosion expand and occupy a volume of about 6-10 times greater than that of steel resulting in the formation of cracks and finally in the failure of structures as shown in Figures 1 and 2.

Penetration of corrosion inducing agents such as chloride ions and carbon dioxide increased at the places of cracks, which further increases the corrosion [2]. Corrosion in concrete structures can be prevented by using low permeable concrete which minimizes the penetration of corrosion inducing agent, and the high resistivity of concrete restricts the corrosion rate by reducing the flow of current from anode to cathode [3].

\section{Half-Cell Potential Method}

Detection and evaluation of probability of corrosion in RC structures are essential. Proper corrosion monitoring of the concrete structures has been required for planning maintenance and replacement of the concrete structures. The most 


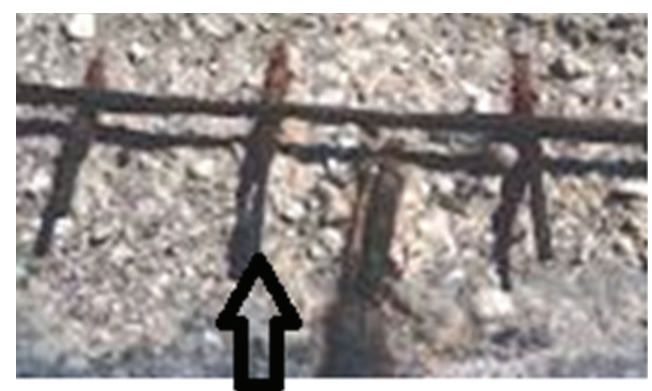

Deterioration due to corrosion

FIgURE 1: Deterioration resulting from corrosion.

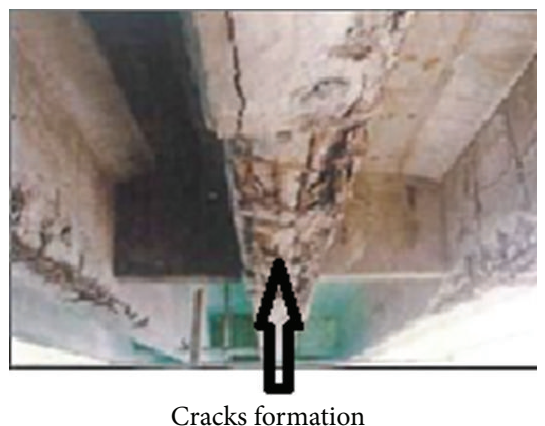

FIGURE 2: Cracks formation.

appropriate repair strategy can be selected for a distressed concrete structure by determining the corrosion status of reinforcing bars [4]. Repair of concrete structures without understanding the root cause of failure may be unsuccessful. If a cracked concrete patched without any treatment to the corroded steel, corrosion will likely continue and result in failure of patch work. Several methods for detecting corrosion activity discussed by authors in their previous paper [5] have been presented in Table 1.

There are several methods available for detecting and evaluating the corrosion in reinforcement steel as presented in Table 1. However, half-cell potential has been recognized by many researchers as the main method to detect the corrosion activity in RC structures [6]. In this method potential difference is measured between steel reinforcement and an external electrode with a voltmeter. The half-cell consists of a metal rod immersed in a solution of its own $\left(\mathrm{Cu} / \mathrm{CuSO}_{4}\right.$ or $\left.\mathrm{Ag} / \mathrm{AgCl}\right)$. The metal rod is connected with reinforcement steel by a voltmeter as shown in Figure 3. Some surface preparations including wetting to ensure good electrical connection are necessary. The main application of this method is in situ. External electrode and steel reinforcement are connected through a wet concrete cover as shown in Figure 3.

Interpretation of results of half-cell potential measurement for reinforced concrete structures required high skills and experience, as this only provides information regarding the probability of corrosion instead of rate and nature of corrosion [7]. Availability of oxygen, cover thickness, and concrete resistivity are few factors influencing the results of

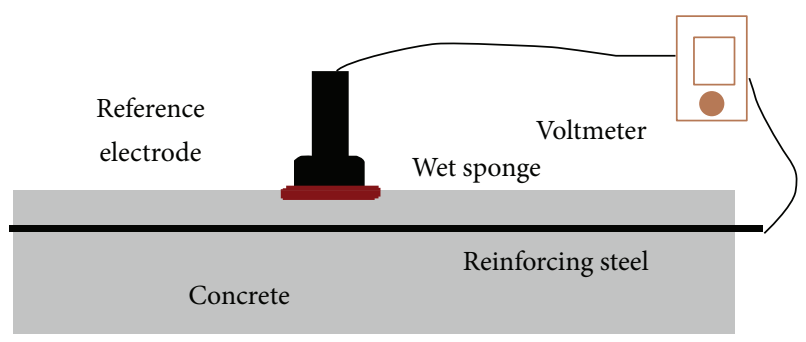

FIGURE 3: Setup of half-cell potential measurement.

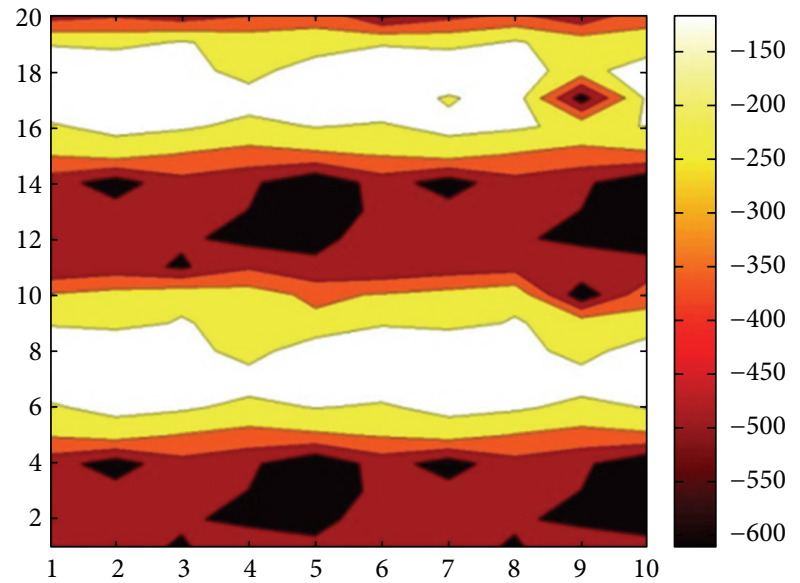

FIGURE 4: Half-cell potential contour.

half-cell potential test. This method evaluates the potential difference on the exposed surface of concrete structures. The potential can be measured at any point on the surface or average of several measurements taken from different points on the same surface may be considered for evaluating the probability of corrosion. More negative value of measured half-cell potential indicates more probability of corrosion, as indicated in Table 2 according to ASTM C 876 for $\mathrm{Cu} / \mathrm{CuSO}{ }_{4}$ half-cell.

This half-cell potential is also known as open circuit potential and is measured at several distinct points over a given area to be surveyed. Measured half-cell potential values can be used to plot a potential contour for the surface of reinforced concrete structure and this potential contour map as shown in Figure 4 can be used to evaluate the probability of corrosion at different points on the surface of the concrete structures. Portions of the structures likelihood of high corrosion activity can be obtained and identified by their high negative potentials.

\section{Few Recently Conducted Corrosion Monitoring Activities}

Several techniques have been reported in previous literatures that can be used for monitoring and evaluating the corrosion of rebars in concrete structures for diagnosing the cause and effect of corrosion. Few such studies performed by different researchers have been presented in Table 3. 
TABLE 1: Methods for evaluating corrosion in concrete structures [5].

\begin{tabular}{|c|c|c|c|c|}
\hline S. no. & Method & Advantages & Limitations & Principle \\
\hline 1 & $\begin{array}{l}\text { Galvanostatic pulse } \\
\text { method }\end{array}$ & $\begin{array}{l}\text { Measures half-cell potential and } \\
\text { electrical resistance simultaneously }\end{array}$ & Unstabilized readings & $\begin{array}{l}\text { Based on the polarization of rebar by } \\
\text { means of small constant current }\end{array}$ \\
\hline 2 & $\begin{array}{l}\text { Linear polarization } \\
\text { resistance (LPR) }\end{array}$ & $\begin{array}{l}\text { Rapid and requires only localized } \\
\text { damage, more detailed information }\end{array}$ & $\begin{array}{l}\text { Measurements are } \\
\text { affected by temperature } \\
\text { and humidity }\end{array}$ & $\begin{array}{l}\text { Electrical conductivity of fluid can be } \\
\text { related to its corrosiveness }\end{array}$ \\
\hline 3 & Half-cell potential & $\begin{array}{l}\text { Simple, portable, results in the form } \\
\text { of equipotential contours }\end{array}$ & $\begin{array}{l}\text { Needs preparation, } \\
\text { saturation required, not } \\
\text { very accurate, and time } \\
\text { consuming }\end{array}$ & $\begin{array}{l}\text { Electric potential of rebars is measured } \\
\text { relative to half-cell and indicates } \\
\text { probability of corrosion }\end{array}$ \\
\hline 4 & $\begin{array}{l}\text { Time domain } \\
\text { reflectometry } \\
\quad(\text { TDR })\end{array}$ & $\begin{array}{c}\text { More robust, easy, and locates } \\
\text { corrosion and identifies extent of } \\
\text { damage }\end{array}$ & Less sensitive & $\begin{array}{l}\text { By applying a sensor wire alongside of the } \\
\text { reinforcement a transmission line is } \\
\text { created. Physical defects of the } \\
\text { reinforcement will change the } \\
\text { electromagnetic properties of the line }\end{array}$ \\
\hline 5 & $\begin{array}{l}\text { Ultrasonic guided } \\
\text { waves }\end{array}$ & $\begin{array}{l}\text { Identify location and magnitude of } \\
\text { corrosion }\end{array}$ & Not very reliable & Based on propagation of ultrasonic waves \\
\hline 6 & $\begin{array}{l}\text { X-ray diffraction } \\
\text { and atomic } \\
\text { absorption }\end{array}$ & Simple and reliable & Hazardous & $\begin{array}{l}\text { Intensity of } \mathrm{X} \text {-ray beams reduces while } \\
\text { passing through a material }\end{array}$ \\
\hline
\end{tabular}

TABle 2: Presents criteria according to ASTM C876 for $\mathrm{Cu} / \mathrm{CuSO}_{4}$.

\begin{tabular}{lcc}
\hline S. no. & Half-cell potential $(\mathrm{mV})$ & Probability of corrosion \\
\hline 1 & $>-200$ & $10 \%$ \\
2 & -200 to -350 & $50 \%$ \\
3 & $<-350$ & $90 \%$ \\
\hline
\end{tabular}

\section{Methods to Protect Structures from Corrosion}

To increase the service life of RC structures, it is required to protect reinforcing steel completely from being corroded. Several chemical and mechanical methods are developed to prevent concrete structures from corrosion by retarding the corrosion rate and by controlling corrosion through reducing permeability of concrete and reducing the ingress of harmful ions such as oxygen and moisture, and some protective systems have been used in the form of coating. Different corrosion inhibitors and protecting systems have been discussed in Table 4 .

\section{Relative Limitations of Half-Cell Potential Method}

Manually measuring potential values at different points on a large structure is tedious work. Therefore, automatic evaluating method is required. Half-cell potential measurements are widely used in structural engineering to assess the likelihood of corrosion. HCP measurements are found to be associated with several practical limitations such as (1) establishing connection with reinforcement, especially in structures with large concrete cover, (2) properly wetting the concrete cover for establishing proper connection between reference electrode and reinforcement, and (3) availability of oxygen, cover thickness, and concrete resistivity which can influence the results of half-cell potential test.

HCP method only provides the evaluation of the point likely to be corroded and no assessment of the corrosion rate. Half-cell potential values are indicative of the probability of corrosion activity of reinforcement located beneath the reference electrode only if the steel rebars are electrically well connected to the voltmeter. Half-cell potential method cannot provide reliable results with epoxy coated reinforcement or with coated concrete surfaces. Moist or wetting condition of concrete can influence the results of half-cell potential method, or it is important to assure the sufficient wetting of concrete to complete the setup for valid half-cell potential measurement. If measured value of the HCP varies with time, prewetting of the concrete is required. It is essential to thoroughly wet the concrete surface and allow sufficient time for the moisture to penetrate the surface layer to stabilize the potential. ASTM C-876 emphasizes that if the measured value of half-cell potential changes with time surface of concrete should be wet for at least $5 \mathrm{~min}$.

It has been observed from literature that results of HCP mapping required careful interpretation. To interpret HCP data, factors such as variation in moisture content, chloride content, and concrete electrical resistance are required to be considered as all these parameters have a significant influence on the readings.

The major drawback is that HCP requires a localized breakout of the concrete cover to provide an electrical connection to the steel reinforcement. HCP results are highly influenced by the composition of the deteriorated concrete. Therefore, interpretation criteria might be different for different deterioration types. Shortcomings of HCP measurements result from the fact that the potentials are measured not near rebars but on concrete surface. Compensation is required to get more reliable results. 
TABLE 3: Several recent corrosion studies.

\begin{tabular}{lll}
\hline Reference & Study performed & Significant observations \\
\hline & $\begin{array}{l}\text { Presented a tool for the interpretation of } \\
\text { the results of half-cell potential } \\
\text { measurement. It relates half-cell potential } \\
\text { values to the probability of corrosion } \\
\text { through concrete resistivity, cover }\end{array}$ & $\begin{array}{l}\text { In concrete with low resistivity potential } \\
\text { distribution on surface represents } \\
\text { potential at steel concrete interface. }\end{array}$ \\
Pour-Ghaz & $\begin{array}{l}\text { thickness, temperature and anode to } \\
\text { et al., 2009 [7] }\end{array}$ & $\begin{array}{l}\text { Fotter results interpretation of } \\
\text { potential readings can be done in } \\
\text { accordance with resistivity. }\end{array}$ \\
& $\begin{array}{l}\text { solving Laplace's equation, relating } \\
\text { corrosion current with average potential } \\
\text { on the surface, potential difference on the } \\
\text { concrete surface, temperature, resistivity, } \\
\text { and concrete cover. }\end{array}$ & $\begin{array}{l}\text { With the increase in concrete cover } \\
\text { difference between surface and interface } \\
\text { potential increases. }\end{array}$ \\
\end{tabular}
Comments and concrete cover.

$\begin{array}{ll}\text { Song and } & \begin{array}{l}\text { Reviewed several electrochemical and } \\ \text { nondestructive testing methods for the }\end{array} \\ \text { Saraswathy, } & \begin{array}{l}\text { assessment of corrosion in concrete } \\ \text { structures. }\end{array}\end{array}$

Reviewed mechanism of corrosion, corrosion monitoring techniques, and methodologies to predict the remaining Ahmad, 2003 service life of structures.

[3] Observed that corrosion rate is affected by $\mathrm{pH}$ of electrolyte, availability of oxygen, capillary water, and concentration of $\mathrm{FE}^{2+}$ in the concrete near the reinforcement.

Described different corrosion monitoring techniques such as half-cell potential Bjegovic et al., 2000 [2] measurement, macrocell current measurement, linear polarization method, Geocor 6, electrochemical impedance spectroscopy, Galvanostatic pulse method, and scanning reference electrode method.

Presented an overview of corrosion process and nondestructive evaluation techniques

Carino, 1999 [4] such as half-cell potential method, concrete resistivity test, and the linear polarization method.

Presented Galvanostatic pulse transient technique for evaluating the corrosion rate

So and Millard, 2007 [8] in reinforced concrete structures and also presented the advantages of this technique over linear polarization (LPR) method.

Discussed results of a study conducted on concrete specimens with different cement,

Pradhan and steel, and varying water/cement ratios. Bhattacharjee, Specimens are subjected to $3 \%$ sodium 2009 [9] chloride solution and half-cell potential measurements were carried out to evaluate corrosion activity.
More realistic results can be obtained by considering availability of oxygen and increasing the test points. More experimental validation of the model is required to increase the confidence.
Combining several techniques can provide more information about corrosion state of steel bars.

An integrated monitoring system for new and existing concrete structures can reduce inspection cost.

Information regarding corrosion state required three parameters half-cell potential, concrete resistivity, and corrosion current density.
Presented methods are useful
to monitor corrosion in
concrete structures and all
these reviewed methods can
be used to develop more
accurate and better techniques
for monitoring corrosion.
Presented all the aspects of
corrosion, and may be useful
for understanding the
corrosion theory, progress of
corrosion, factors affecting
corrosion, monitoring
techniques and for predicting
service live of structures.

Presented overview of several nondestructive methods with their relative advantages and disadvantages based on experiences and interpretation of results. It is a useful study covering almost all the present corrosion measuring techniques.

Corrosion rate in a concrete structure is governed by several parameters such as moisture content, availability of oxygen, and temperature. So, for better results it is necessary to repeat corrosion rate measurement in regular time interval.

Corrosion rates calculated from Galvanostatic pulse transient technique are generally higher than those evaluated from LPR technique.

A useful review has been presented by considering the behavior of electrolytic cells.

It is a useful study presenting a relatively more reliable technique for measuring corrosion rate in $\mathrm{RC}$ structures.

Critical chloride content causing corrosion initiation is influenced by steel type, cement type, and w/c ratio. Found half-cell potential as a parameter indicating rebar corrosion initiation in chloride contaminated concrete.
It has been observed from this study that corrosion initiation time is influenced by the rate of ingress of chloride ions and depassivation of protective passive film. 
TABLE 3: Continued.

\begin{tabular}{|c|c|c|c|}
\hline Reference & Study performed & Significant observations & Comments \\
\hline $\begin{array}{l}\text { Hussain and } \\
\text { Ishida, } 2012 \text { [1] }\end{array}$ & $\begin{array}{l}\text { Performed multivariable laboratory } \\
\text { experiments to evaluate effect of oxygen on } \\
\text { reinforcement corrosion under different } \\
\text { environmental conditions and also } \\
\text { explained half-cell potential measurement } \\
\text { in different conditions such as submerged } \\
\text { exposure condition and under cyclic } \\
\text { wetting-drying exposure. }\end{array}$ & $\begin{array}{l}\text { It was observed that oxygen is an } \\
\text { influencing factor for corrosion only for } \\
\text { concretes placed completely under } \\
\text { water. }\end{array}$ & $\begin{array}{l}\text { Results of this analysis can be } \\
\text { used for calibrating half-cell } \\
\text { potential measurements } \\
\text { performed under water. }\end{array}$ \\
\hline $\begin{array}{l}\text { Cairns and } \\
\text { Melville, } 2003 \\
{[10]}\end{array}$ & $\begin{array}{l}\text { Performed nondestructive electrochemical } \\
\text { measurements of corrosion to evaluate } \\
\text { effect of protective coatings on the } \\
\text { reliability of these tests. }\end{array}$ & $\begin{array}{l}\text { It has been observed from results that } \\
\text { half-cell potential measurements were } \\
\text { not affected significantly by coating. }\end{array}$ & $\begin{array}{l}\text { Useful study to evaluate } \\
\text { reliability of corrosion } \\
\text { monitoring techniques. }\end{array}$ \\
\hline $\begin{array}{l}\text { Elsener, } 2001 \\
\text { [11] }\end{array}$ & $\begin{array}{l}\text { Discussed about application and } \\
\text { limitations of half-cell potential mapping } \\
\text { for assessing reinforced concrete structures } \\
\text { to evaluate repair work. } \\
\text { Repairs include replacement of chloride } \\
\text { contaminated concrete, electrochemical } \\
\text { chloride removal, electrochemical } \\
\text { realkalization and application of corrosion } \\
\text { inhibitors. }\end{array}$ & $\begin{array}{l}\text { For interpretation of half-cell potential } \\
\text { readings, it requires precise } \\
\text { understanding of corrosion protection } \\
\text { mechanisms and good knowledge and } \\
\text { experience in half cell potential } \\
\text { mapping. }\end{array}$ & $\begin{array}{l}\text { A useful study explaining } \\
\text { half-cell potential mapping } \\
\text { and effect of corrosion } \\
\text { repairing over the results } \\
\text { provided by half-cell potential } \\
\text { method. }\end{array}$ \\
\hline $\begin{array}{l}\text { Parthiban et al., } \\
2006 \text { [12] }\end{array}$ & $\begin{array}{l}\text { Carried out simultaneous potential } \\
\text { measurements on different points on } \\
\text { concrete slab, using computer based I/O } \\
\text { cards and also developed software based } \\
\text { on ASTM C- } 876 \text { for interpretation of } \\
\text { measured values. }\end{array}$ & $\begin{array}{l}\text { Among the various electrochemical } \\
\text { methods potential measurement has } \\
\text { been the mostly used field technique for } \\
\text { detecting corrosion activity in steel. } \\
\text { Manually measuring half-cell potential } \\
\text { values is a tedious job on a large } \\
\text { structure, so an automatic system to } \\
\text { evaluate the half-cell potential values is } \\
\text { present. }\end{array}$ & $\begin{array}{l}\text { An automated useful method } \\
\text { to evaluate half-cell potential } \\
\text { at different points on a large } \\
\text { structure simultaneously is } \\
\text { present. } \\
\text { This method can reduce time } \\
\text { required to evaluate potential } \\
\text { values at different points for } \\
\text { monitoring the corrosion. }\end{array}$ \\
\hline
\end{tabular}

It has been observed that specimens casted in seawater develop early

Studied corrosion evaluation of the steel bars embedded in underwater concrete.

Moon and Shin, Performed accelerated corrosion tests on 2006 [13] three series of reinforced underwater concrete with different admixtures in different conditions. corrosion of steel bars.

Among all the specimens, in OPC manufactured concrete corrosion rate is fastest and exceeds threshold value earlier than other specimens.

Mineral admixtures are more effective in delaying the development of

corrosion in underwater concrete.

Described pitfalls in assessment of chloride induced corrosion through electrochemical methods.

Poursaee and Hansson, 2009 [14]

\section{Factors influencing the results of} electrochemical processes are found to make more measurements in short period to reduce the costs, choosing appropriate electrochemical method, and laboratory tests are usually conducted on young and immature concrete.

Performed a study to estimate the corrosion activity of steel bars embedded in two types of concrete specimens, Soleymani and ordinary and high performance, applying Ismail, 2004 [15] different corrosion measurement methods. Methods applied are half-cell potential, linear polarization method, Tafel plot, and other chloride content methods.
Results of electrochemical assessment may not represent actual condition of rebars.
A careful study on antiwashout underwater concrete to evaluate effect of different admixtures on corrosion of steel bars.
Results indicated that all these method would assess the same level of corrosion in only $24 \%$ of specimens.
Explained the pitfalls in electrochemical assessment of chloride induced corrosion of steel, which can be utilized to regulate the results of measurements.
Presented a useful comparison between different corrosion measurement methods. This study can be used by researchers to select better corrosion monitoring technique. 
TABLe 3: Continued.

\begin{tabular}{llll}
\hline Reference & Study performed & Significant observations & Comments \\
\hline & $\begin{array}{l}\text { Performed accelerated corrosion test to } \\
\text { evaluate durability of marine concrete } \\
\text { structures subjected to fatigue loading with }\end{array}$ & $\begin{array}{l}\text { Deterioration is faster under fatigue } \\
\text { loading than static loading. }\end{array}$ & $\begin{array}{l}\text { Presents significant findings } \\
\text { about the effect of fatigue }\end{array}$ \\
$\begin{array}{l}\text { Ahn and Reddy, } \\
\text { different water cement ratios. Ultimate }\end{array}$ & $\begin{array}{l}\text { Durability decreased with increase in } \\
\text { strength testing followed by half-cell }\end{array}$ & $\begin{array}{l}\text { loading and water cement } \\
\text { watio over the durability and }\end{array}$ \\
& $\begin{array}{l}\text { potential measurement and crack } \\
\text { investigations has been performed. }\end{array}$ & & life of the structures.
\end{tabular}

Studied effect of conductivity and cover depth on potential and macrocell current distribution.

Elsener, 2002 Also, discussed consequences of [17] monitoring corrosion through half-cell potential mapping and polarization measurement technique on locally corroded rebars.

Performed laboratory experiments to evaluate half-cell potential, corrosion Alhozaimy et al. current, and concrete resistivity over 2012 [18] chloride contaminated concrete specimens, to investigate the phenomenon of high corrosion at intersection of steel rebars in the wall footing.

Performed half-cell potential and corrosion current density test on concrete specimens to monitor corrosion activity.

Duong et al., 2013 [19] This corrosion activity had been monitored to evaluate the effect of leaching on carbonation and corrosion initiation of steel bars.

Low electrolyte conductivity and cover make it possible to locate anode of the macrocell by potential measurements.
Discussed about influence of macrocell corrosion on corrosion monitoring.

\section{Observed that experimental}

measurements are higher at intersection of steel bars in comparison with the areas between them. This high corrosion rate is found to be due to coupled effects of corrosive binding wire materials, electrical connectivity, reduction in centre to centre spacing of steel rebars, and poor concrete microstructures.

Observed that with the increase in leaching exposure carbonation depth also increases.

Replacing cement partially with fly ash reduces the resistance against carbonation and leaching.

Observed that short circuit influence of embedded steel can be used to evaluate the rate of corrosion on the surface of the bars.

Phenomenon reported in this paper is new and interesting. More and extensive research is required to understand the effect of all factors influencing the corrosion at intersection of steel rebars.

Presents the performance of half-cell potential measurement and corrosion current density to detect corrosion due to leaching activity. It has been observed that suitable test methods are required.

More validation of methods is required on concrete with wider range of resistivity. direct connection to the reinforcement.

Half-cell potential and linear polarization measurements have been performed for one year to evaluate the parameters

Jung et al., 2003 affecting the corrosion rate. Measurements have been made to predict the remaining service life of land concrete affected from steel corrosion.

Presented a new technique to investigate corrosion of steel bars in concrete using

Quantitative polarization method provides more precise results than those of half-cell potential method in evaluating the corrosion activity.
Comparison between methods helps researchers to select better techniques for evaluating residual service life of structures. ground penetrating radar (GPR) and modified half-cell potential method.

Lai et al., 2013

[22]

\section{Attempted to measure potential difference} with two moving probes and making no connection with steel bars.

Performed half-cell potential measurements to estimate corrosion of reinforcing steel bars embedded in

Leelalerkiet et al., 2004 [23] concrete slabs under cyclic wet and dry exposures. Influence of void over potential distribution and current distribution has also been investigated.
Results show that both GPR and modified HCP methods can measure electrochemical corrosion process.
More researches are required to relate laboratory results with real time structures
Observed from results that half-cell potential is marginal successful In the void specimens half-cell potential values required compensation for more reliable results.
Useful study to demonstrate corrosion estimation in both intact and void specimens. 
TABle 3: Continued.

\begin{tabular}{llll}
\hline Reference & Study performed & Significant observations & Comments \\
\hline $\begin{array}{l}\text { Faber and } \\
\text { Sorensen, } 2002 \\
{[24]}\end{array}$ & $\begin{array}{l}\text { Discussed the application of half-cell } \\
\text { potential measurements to evaluate the } \\
\text { probability of corrosion and repair after } 50 \\
\text { years. This is explained on a corroded } \\
\text { concrete structure. }\end{array}$ & $\begin{array}{l}\text { It has been observed that half-cell } \\
\text { potential measurements may be utilized } \\
\text { to update the probability of corrosion. }\end{array}$ & $\begin{array}{l}\text { Provided a study on the } \\
\text { utilization of half-cell } \\
\text { potential method. }\end{array}$ \\
\hline $\begin{array}{l}\text { Hussain, 2011 } \\
{[25]}\end{array}$ & $\begin{array}{l}\text { Investigated underwater half-cell corrosion } \\
\text { potential in submerged RC structures and } \\
\text { compares with various other relative } \\
\text { humidity conditions. }\end{array}$ & $\begin{array}{l}\text { Half-cell potential values for submerged } \\
\text { underwater RC structures are not } \\
\text { representing actual corrosion rate and } \\
\text { these values are required to be } \\
\text { calibrated using the experiment results } \\
\text { of this research. }\end{array}$ & $\begin{array}{l}\text { This study enables researches } \\
\text { to perform underwater } \\
\text { corrosion measurement for } \\
\text { submerged RC structures. }\end{array}$ \\
\hline
\end{tabular}

TABLE 4: Techniques to protect concrete from corrosion.

\begin{tabular}{|c|c|}
\hline Protective techniques & Reference \\
\hline $\begin{array}{l}\text { Fly ash increased the corrosion resistance of concrete by reducing porosity of concrete porosity, } \\
\text { which decreases penetration rate of harmful ions. }\end{array}$ & Xu et al., 2012 [26] \\
\hline $\begin{array}{l}\text { Super-plasticizers and mineral admixtures like fly ash, granulated blast furnace slag, and } \\
\text { pozzolanic materials reduce the corrosion rate. }\end{array}$ & Maslehuddin et al., 1992 [27] \\
\hline $\begin{array}{l}\text { Use of low-nickel stainless steel rebars reduces corrosion rate by providing high alkaline concrete } \\
\text { pore solution }\end{array}$ & Criado et al., 2011 [28] \\
\hline Penetrating amino alcohol corrosion inhibitor reduces the steel corrosion. & Jamil et al., 2005 [29] \\
\hline Calcium nitrite based corrosion inhibitor reduces the carbonation depth & Sideris and Savva, $2005[30]$ \\
\hline Calcium nitrite based inhibitor improves the chloride threshold value. & Ann et al., 2006 [31] \\
\hline Benzotriazole as a corrosion inhibitor improves corrosion resistance. & Ann et al., 2006 [31] \\
\hline Polyvinylpyrrolidone improves corrosion resistance of concrete when added. & Gürten et al., 2005 [32] \\
\hline Alkylamino alcohol increases the corrosion resistance. & Morris and Vázquez 2002 [33] \\
\hline Fusion bonded epoxy coated (FBEC) steel bars are beneficial in decreasing corrosion. & $\begin{array}{l}\text { Al-Dulaijan et al., } 2012[34] \\
\text { Darwin and Scantlebury, 2002 [35] }\end{array}$ \\
\hline Alkanolamine based corrosion inhibitor with inorganic coating. & Batis et al., 2003 [36] \\
\hline Steel bars coated with DINITROL AV 30 shows good corrosion resistance. & Monticelli et al., 2000 [37] \\
\hline $\begin{array}{l}\text { Use of double combination of calcium nitrite and ground granulated blast furnace slag (GGBFS), } \\
\text { and triple combination of calcium nitrite, silica fume, and fly ash/GGBFS protect concrete } \\
\text { exposed to severe corrosive environments. }\end{array}$ & Civjan et al., 2005 [38] \\
\hline $\begin{array}{l}\text { Aminoalcohol based mixed (organic/inorganic) inhibitors, when used as admixture or as a repair } \\
\text { product, reduces the rate of corrosion. }\end{array}$ & Wombacher et al., 2004 [39] \\
\hline $\mathrm{ZnO}$ reduces the concrete porosity and chloride content at rebar level and reduces the corrosion & de Rincón et al., 2002 [40] \\
\hline By providing high chromium steel, corrosion rate can be decreased. & Nachiappan and Cho, 2005 [41] \\
\hline $\begin{array}{l}\text { CFRP laminates reduce the expansion caused by corrosion and also control the corrosion rate by } \\
\text { decreasing the loss of mass. }\end{array}$ & Badawai and Soudki, 2005 [42] \\
\hline
\end{tabular}

\section{Conclusion}

Failure of concrete structures due to corrosion of embedded rebars is a major problem causing significant loss of money and time. Hence, there is a need to fully understand the root causes of failure before the repairing for effective remediation. An effective method to measure corrosion is a fundamental requirement for planning maintenance, repairing, and removal for reinforced concrete structures. Information regarding corrosion state required three parameters: half-cell potential, concrete resistivity, and corrosion current density. Corrosion rate in a concrete structure is governed by several parameters such as moisture content, availability of oxygen, and temperature. So, for better results it is necessary to repeat corrosion rate measurement in regular time interval.

Half-cell potential measurement is the most widely used technique for the evaluation of corrosion of steel in concrete. However, in interpreting the data environmental factors should be taken into account. For interpretation of halfcell potential readings, it requires precise understanding of corrosion protection mechanisms and good knowledge and experience in half-cell potential mapping. In present research it has been observed that half-cell potential measurements are useful in the following purposes:

(1) to assess the corrosion condition of the reinforcement by locating corroded bars, 
(2) for the condition assessment of a concrete structure,

(3) to locate and decide the position of further detailed destructive and nondestructive testing,

(4) evaluate the efficiency of repair work through corrosion state monitoring of repaired concreter structures.

In concrete with low resistivity potential distribution on surface represents potential at steel concrete interface. For better results interpretation of potential readings can be done in accordance with resistivity. With increase in concrete cover difference between surface and interface potential increases.

Content of this paper can be utilized to understand the principal of half-cell potential method, to plan investigation of corroded structures, and to select suitable corrosion monitoring technique.

\section{Conflict of Interests}

The authors declare that there is no conflict of interests regarding the publication of this paper.

\section{References}

[1] R. R. Hussain and T. Ishida, "Multivariable empirical analysis of coupled oxygen and moisture for potential and rate of quantitative corrosion in concrete," Journal of Materials in Civil Engineering, vol. 24, no. 7, pp. 950-958, 2012.

[2] D. Bjegovic, D. Mikulic, and D. Sekulic, "Non destructive corrosion rate monitoring for reinforced concrete structures," in Proceedings of the 15th World Conference on Non-Destructive Testing (WCNDT '00), Roma, Italy, 2000.

[3] S. Ahmad, "Reinforcement corrosion in concrete structures, its monitoring and service life prediction-a review," Cement and Concrete Composites, vol. 25, no. 4-5, pp. 459-471, 2003.

[4] N. J. Carino, "Nondestructive techniques to investigate corrosion status in concrete structures," Journal of Performance of Constructed Facilities, vol. 13, no. 3, pp. 96-106, 1999.

[5] S. K. Verma, S. S. Bhadauria, and S. Akhtar, "Review of non destructive testing methods for condition monitoring of concrete structures," Journal of Construction Engineering, vol. 2013, Article ID 834572, 11 pages, 2013.

[6] H. Song and V. Saraswathy, "Corrosion monitoring of reinforced concrete structures-a review," International Journal of Electrochemical Science, vol. 2, pp. 1-28, 2007.

[7] M. Pour-Ghaz, O. B. Isgor, and P. Ghods, "Quantitative interpretation of half-cell potential measurements in concrete structures," Journal of Materials in Civil Engineering, vol. 21, no. 9, pp. 467-475, 2009.

[8] H. So and S. G. Millard, "Assessment of corrosion rate of reinforcing steel in concrete using Galvanostatic pulse transient technique," International Journal of Computing Science and Mathematics, vol. 1, no. 1, pp. 83-88, 2007.

[9] B. Pradhan and B. Bhattacharjee, "Half-cell potential as an indicator of chloride-induced rebar corrosion initiation in RC," Journal of Materials in Civil Engineering, vol. 21, no. 10, pp. 543552, 2009.

[10] J. Cairns and C. Melville, "The effect of concrete surface treatments on electrical measurements of corrosion activity," Construction and Building Materials, vol. 17, no. 5, pp. 301-309, 2003.
[11] B. Elsener, "Half-cell potential mapping to assess repair work on RC structures," Construction and Building Materials, vol. 15, no. 2-3, pp. 133-139, 2001.

[12] T. Parthiban, R. Ravi, and G. T. Parthiban, "Potential monitoring system for corrosion of steel in concrete," Advances in Engineering Software, vol. 37, no. 6, pp. 375-381, 2006.

[13] H. Y. Moon and K. J. Shin, "Evaluation on steel bar corrosion embedded in antiwashout underwater concrete containing mineral admixtures," Cement and Concrete Research, vol. 36, no. 3, pp. 521-529, 2006.

[14] A. Poursaee and C. M. Hansson, "Potential pitfalls in assessing chloride-induced corrosion of steel in concrete," Cement and Concrete Research, vol. 39, no. 5, pp. 391-400, 2009.

[15] H. R. Soleymani and M. E. Ismail, "Comparing corrosion measurement methods to assess the corrosion activity of laboratory OPC and HPC concrete specimens," Cement and Concrete Research, vol. 34, no. 11, pp. 2037-2044, 2004.

[16] W. Ahn and D. V. Reddy, "Galvanostatic testing for the durability of marine concrete under fatigue loading," Cement and Concrete Research, vol. 31, no. 3, pp. 343-349, 2001.

[17] B. Elsener, "Macrocell corrosion of steel in concreteimplications for corrosion monitoring," Cement and Concrete Composites, vol. 24, no. 1, pp. 65-72, 2002.

[18] A. Alhozaimy, R. R. Hussain, R. Al-Zaid, and A. A. Negheimish, "Investigation of severe corrosion observed at intersection points of steel rebar mesh in reinforced concrete construction," Construction and Building Materials, vol. 37, pp. 67-81, 2012.

[19] V. B. Duong, R. Sahamitmongkol, and S. Tangtermsirikul, "Effect of leaching on carbonation resistance and steel corrosion of cement based materials," Construction and Building Materials, vol. 40, pp. 1066-1075, 2013.

[20] L. Sadowski, "New non-destructive method for linear polarisation resistance corrosion rate measurement," Archives of Civil and Mechanical Engineering, vol. 10, no. 2, pp. 109-116, 2010.

[21] W.-Y. Jung, Y.-S. Yoon, and Y.-M. Sohn, "Predicting the remaining service life of land concrete by steel corrosion," Cement and Concrete Research, vol. 33, no. 5, pp. 663-677, 2003.

[22] W. Lai, T. Kind, M. Stoppel, and H. Wiggenhauser, "Measurement of accelerated steel corrosion in concrete using groundpenetrating radar and a modified half-cell potential method," Journal of Infrastructure Systems, vol. 19, no. 2, pp. 205-220, 2013.

[23] V. Leelalerkiet, J.-W. Kyung, M. Ohtsu, and M. Yokota, “Analysis of half-cell potential measurement for corrosion of reinforced concrete," Construction and Building Materials, vol. 18, no. 3, pp. 155-162, 2004.

[24] M. H. Faber and J. D. Sorensen, "Indicators for inspection and maintenance planning of concrete structures," Structural Safety, vol. 24, no. 2-4, pp. 377-396, 2002.

[25] R. R. Hussain, "Underwater half-cell corrosion potential bench mark measurements of corroding steel in concrete influenced by a variety of material science and environmental engineering variables," Measurement, vol. 44, no. 1, pp. 274-280, 2011.

[26] H. Xu, Z. Chen, B. Xu, and D. Ma, "Impact of low calcium fly ash on steel corrosion rate and concrete-steel interface," The Open Civil Engineering Journal, vol. 6, no. 1, pp. 1-7, 2012.

[27] M. Maslehuddin, Rasheeduzzafar, and A. I. Al-Mana, "Strength and corrosion resistance of superplasticized concretes," Journal of Materials in Civil Engineering, vol. 4, no. 1, pp. 108-113, 1992.

[28] M. Criado, D. M. Bastidas, S. Fajardo, A. Fernández-Jiménez, and J. M. Bastidas, "Corrosion behaviour of a new low-nickel 
stainless steel embedded in activated fly ash mortars," Cement and Concrete Composites, vol. 33, no. 6, pp. 644-652, 2011.

[29] H. E. Jamil, A. Shriri, R. Boulif, M. F. Montemor, and M. G. S. Ferreira, "Corrosion behaviour of reinforcing steel exposed to an amino alcohol based corrosion inhibitor," Cement and Concrete Composites, vol. 27, no. 6, pp. 671-678, 2005.

[30] K. K. Sideris and A. E. Savva, "Durability of mixtures containing calcium nitrite based corrosion inhibitor," Cement and Concrete Composites, vol. 27, no. 2, pp. 277-287, 2005.

[31] K. Y. Ann, H. S. Jung, H. S. Kim, S. S. Kim, and H. Y. Moon, "Effect of calcium nitrite-based corrosion inhibitor in preventing corrosion of embedded steel in concrete," Cement and Concrete Research, vol. 36, no. 3, pp. 530-535, 2006.

[32] A. A. Gürten, M. Erbil, and K. Kayakirilmaz, "Effect of polyvinylpyrrolidone on the corrosion resistance of steel," Cement and Concrete Composites, vol. 27, no. 7-8, pp. 802-808, 2005.

[33] W. Morris and M. Vázquez, "A migrating corrosion inhibitor evaluated in concrete containing various contents of admixed chlorides," Cement and Concrete Research, vol. 32, no. 2, pp. 259267, 2002.

[34] S. U. Al-Dulaijan, M. Maslehuddin, M. Shameem, M. Ibrahim, and M. Al-Mehthel, "Corrosion protection provided by chemical inhibitors to damaged FBEC bars," Construction and Building Materials, vol. 29, pp. 487-495, 2012.

[35] A. B. Darwin and J. D. Scantlebury, "Retarding of corrosion processes on reinforcement bar in concrete with an FBE coating," Cement and Concrete Composites, vol. 24, no. 1, pp. 73$78,2002$.

[36] G. Batis, P. Pantazopoulou, and A. Routoulas, "Corrosion protection investigation of reinforcement by inorganic coating in the presence of alkanolamine-based inhibitor," Cement and Concrete Composites, vol. 25, no. 3, pp. 371-377, 2003.

[37] C. Monticelli, A. Frignani, and G. Trabanelli, "A study on corrosion inhibitors for concrete application," Cement and Concrete Research, vol. 30, no. 4, pp. 635-642, 2000.

[38] S. A. Civjan, J. M. Lafave, J. Trybulski, D. Lovett, J. Lima, and D. W. Pfeifer, "Effectiveness of corrosion inhibiting admixture combinations in structural concrete," Cement and Concrete Composites, vol. 27, no. 6, pp. 688-703, 2005.

[39] F. Wombacher, U. Maeder, and B. Marazzani, "Aminoalcohol based mixed corrosion inhibitors," Cement and Concrete Composites, vol. 26, no. 3, pp. 209-216, 2004.

[40] O. T. de Rincón, O. Pérez, E. Paredes, Y. Caldera, C. Urdaneta, and I. Sandoval, "Long-term performance of $\mathrm{ZnO}$ as a rebar corrosion inhibitor," Cement and Concrete Composites, vol. 24, no. 1, pp. 79-87, 2002.

[41] V. Nachiappan and E. H. Cho, "Corrosion of high chromium and conventional steels embedded in concrete," Journal of Performance of Constructed Facilities, vol. 19, no. 1, pp. 56-61, 2005.

[42] M. Badawi and K. Soudki, "Control of corrosion-induced damage in reinforced concrete beams using carbon fiber-reinforced polymer laminates," Journal of Composites for Construction, vol. 9, no. 2, pp. 195-201, 2005. 

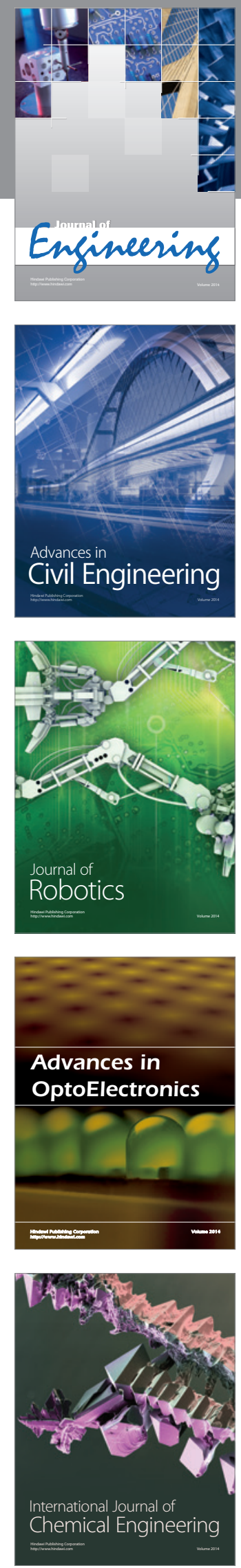

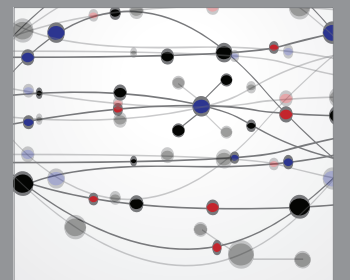

The Scientific World Journal
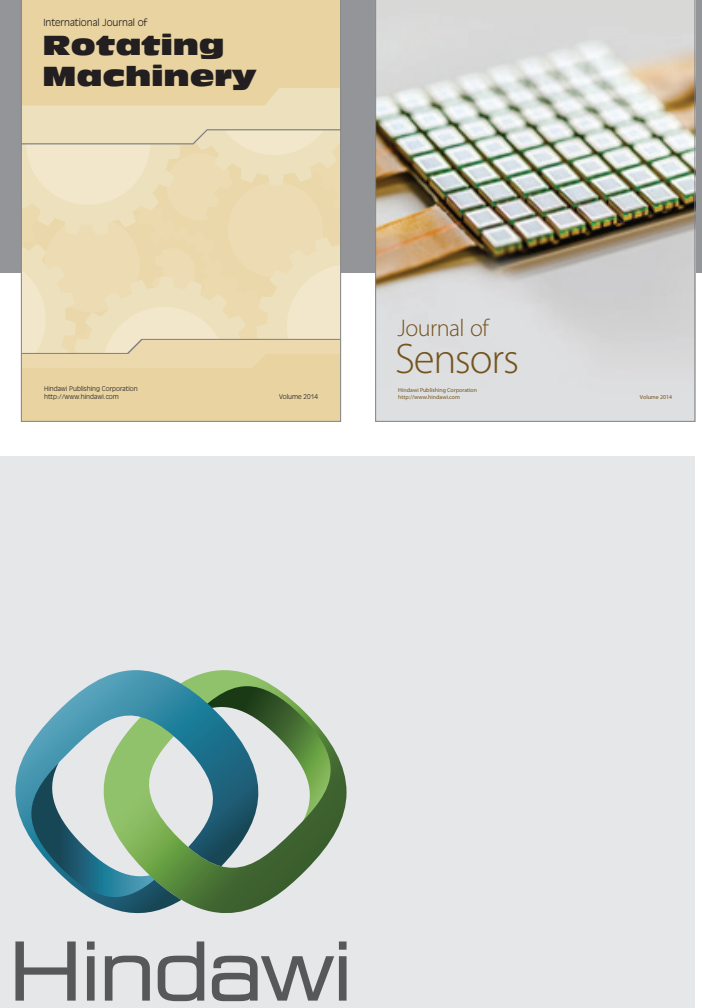

Submit your manuscripts at http://www.hindawi.com
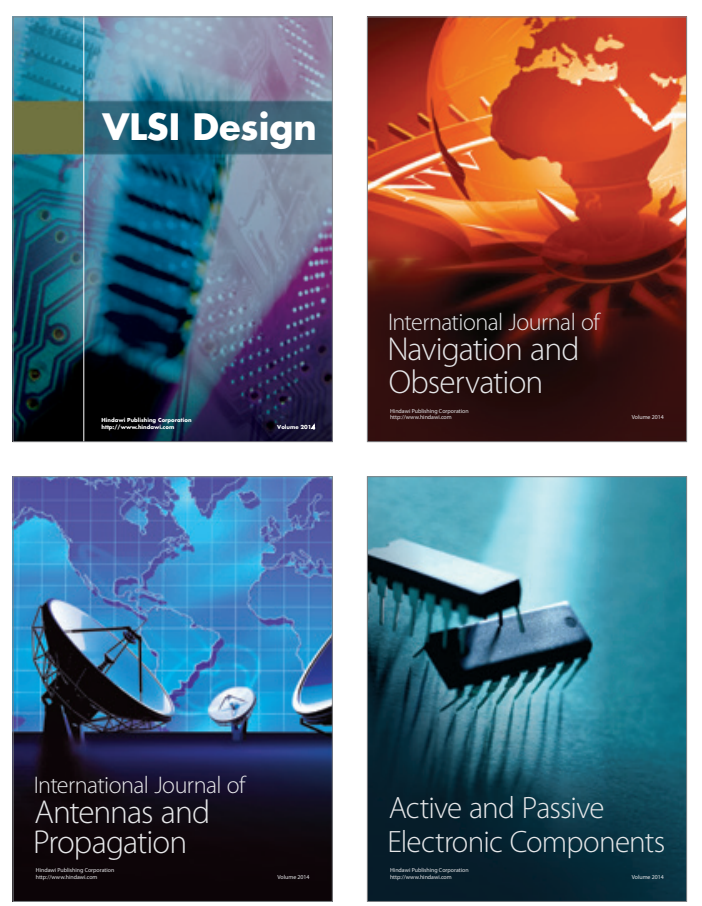
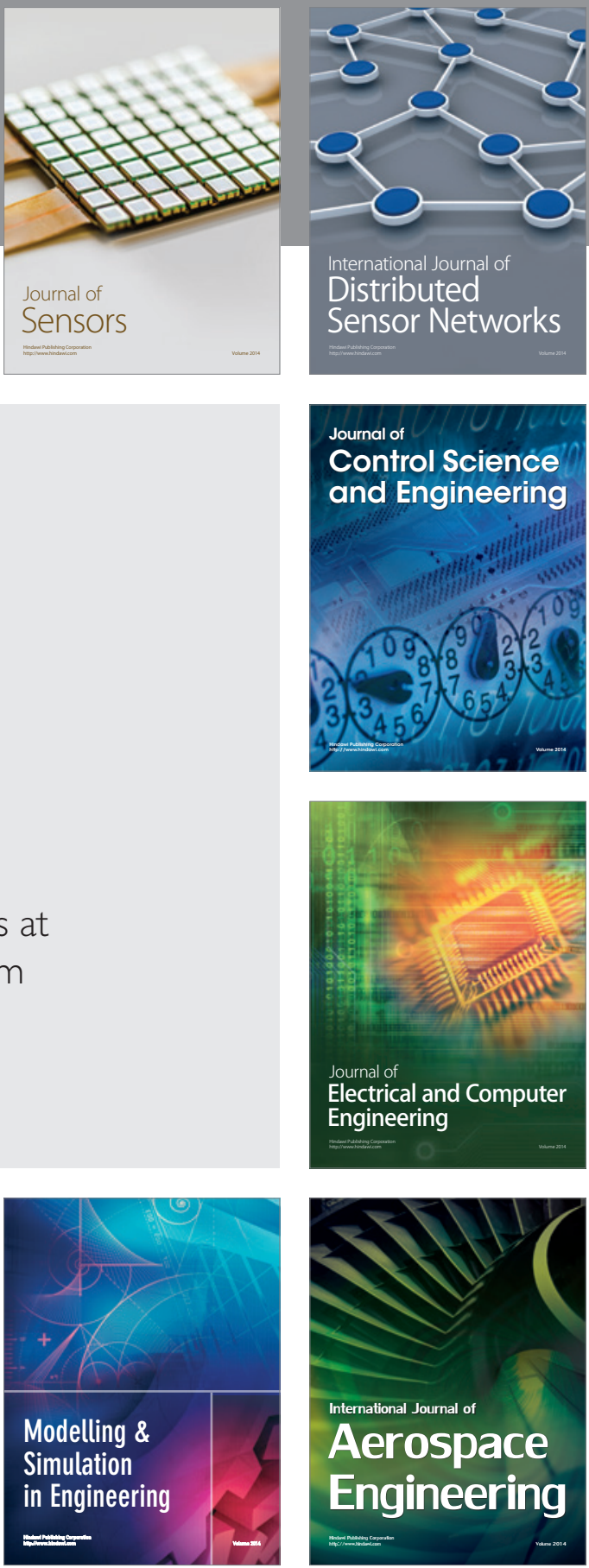

Journal of

Control Science

and Engineering
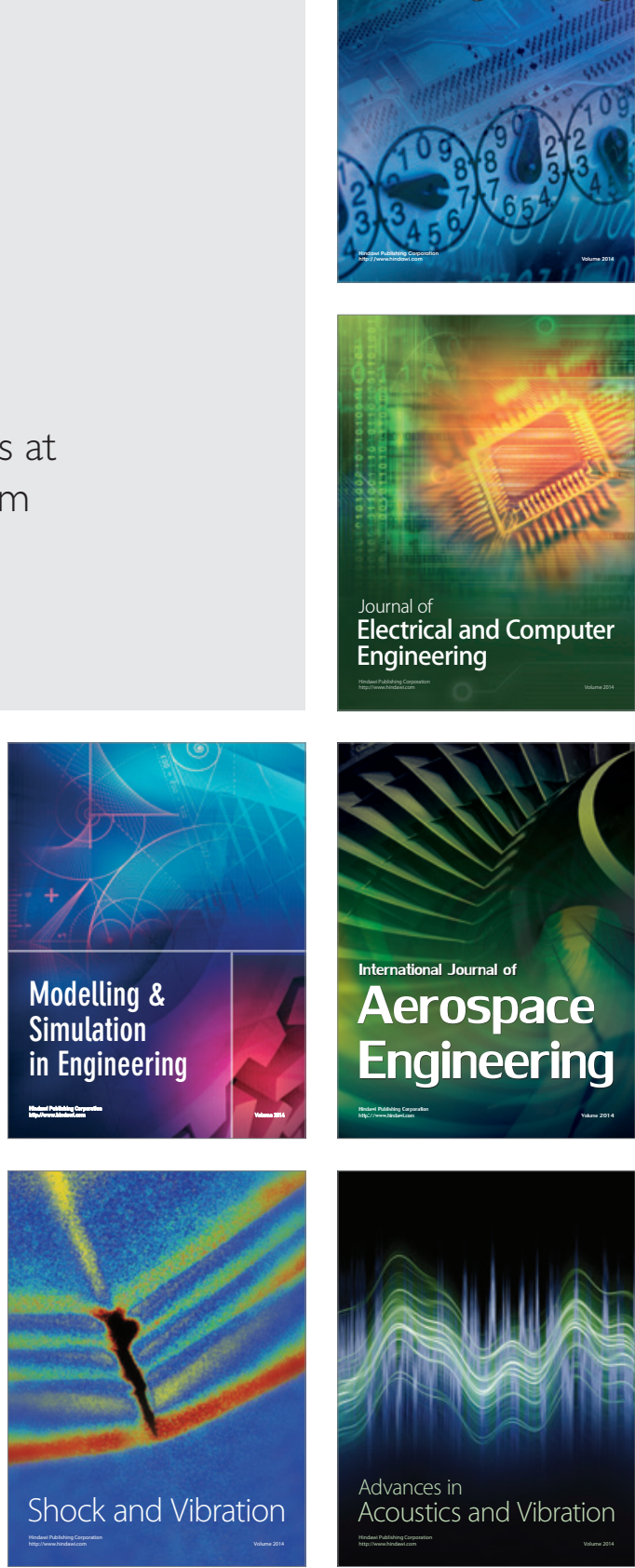